\title{
Influence of temperature on larval survival, development, and respiration in Chasmagnathus granulata (Crustacea, Decapoda)
}

\author{
D. Ismael ${ }^{1.2 .3}, \mathrm{~K}$. Anger $^{2 *} \&$ G. S. Moreira ${ }^{1}$ \\ 'Universidade de São Paulo, Instituto de Biocièncias, CP 11461; São Paulo, \\ SP 05422-970, Brazil \\ 'Biologische Anstalt Helgoland, Meeresstation; 27483 Helgoland, Germany \\ 'Present address: Universidade Estadual Paulista - Centro de Aquicultura (CALNESP) \\ Rodovia Carlos Tonanni, Km 5; Jaboticabal, sP 14870-000, Brazil
}

\begin{abstract}
Larvae of an estuarine yrapsid crab Chasmagnathus yranulata Dand 1851. trom temperate and subtropical regions of South America, were reared in seawater $(32 \%$ at five different constant lemperatures $\left(12,15,18,21,24^{\circ} \mathrm{C}\right)$. Complete larval development from hatching (Zoed () to metamorphosis (Crab) I) occurred in a range from 1.5 to $24^{\circ} \mathrm{C}$ :. Highest survival (60) $\%$ to the first juvenile stage) was observed at $18{ }^{\circ} \mathrm{C}$, while all larvae reared at $12^{\circ} \mathrm{C}$ died before metamorphosis. The duration of development $(D)$ decreased with increasing temperature $(T)$. This relationship is clescribed for all larval stages as a power function (linear regressions after logarithmic transformation of both $D$ and $T)$. The temperature-dependence of the instantaneous clevelopmental rate ( $D$ ') is compared among larval stages and temperatures using the $Q_{11}$ coefficient (van't Hoff's equaltion). Through ail four zoeal stages, this index tends to increase durng development and to (lecrease with increasing $T$ fcomparing ranges $12-18,15-21,18-24^{\circ} \mathrm{C}$ ). In the Megalopa, low $\left(Q_{\text {: }}\right.$ values were found in the range from 15 to 24 " C. In another series of experiments, larvae were reared at constant $18^{\circ} \mathrm{C}$, and their dry weight $(W)$ and respiratory response 10 changes in $T$ were measured in all successive stacyes during the intermoult period (stage (.) of the moulting cycle. Both individual and weight-specific respiration $(R, Q O)$ increased exponentially with increasing $T$. At each temperature, $R$ incredsed significantly during growth and development through successive larval stages. No significantly different $Q O$. values were found in the first three zoeal stages, while a significant decrease with increasing $W$ occurred in the Zoea IV and Megalopa. As in the temperature-dependence of $D$, the respiratory response to changes in temperature $\left(Q_{0,0}\right)$ depends on both the temperature range and the developmental stage, however, with different patterns. In the zoeal stages, the respiratory $Q_{11}$ was minimum $(1.7-2.2)$ at low temperatures $\left(12-18^{\circ} \mathrm{C}\right)$, but maximum $\{2.2-3.0\}$ at $18-24^{\circ} \mathrm{C}$. The Megaiopd, in contrast, showed a stronger metaboilc response in the lower than in the upper temperature range $\left(Q_{10}=2.8\right.$ and 1.7 . respectuvely). We interpret this pattern as an adaptation to a sequence of temperature conditions that should typically be encountered by $C$. granulato larvae during their ontogenetic migrations: hatching in and subsequent export from shallow estuarine lagoons, zoeal development in coastal marine waters, which are on average cooler, return in the Megalopa stage to warm lagoons. We thus propose that high metabolic sensitivity to changes in temperature may serve as a signal stimulating larval migration. so that the zocae should tend to leave warm estuaries and lagoons, whereas the Megalopa should avoid remaining in the cooler marine waters and initiate its migration towards shallow coastal lagoons.
\end{abstract}

- Addressee for all correspondence.

(.) Biologische Anstalt Helgoland, Hamburg 


\section{INTRODUCTION}

The majority of grapsid crabs are intertidal or supratidal species, occupying a great variety of coastal and estuarine habitats. Almost all of them show some degree of adaptation to terrestrial or low-salinity conditions, although most species are still bound to the sea, having a pelagic larval development (Hartnoll, 1988; Anger, 1995). One of these, the semiterrestrial crab Chasmagnathus granulata Dana 1851, lives in supralittoral and mesolittoral zones of South American salt marshes, ranging from Cabo Frio, Brazil $\left(23^{\circ} \mathrm{S}\right)$, to the Gulf of San Matias, Argentina $\left(43^{\circ} \mathrm{S}\right)$, where it is one of the dominating macrobenthic inhabitants (Boschi, 1964). Its first-stage larvae hatch in shallow coastal estuaries and lagoons, from where they are rapidly exported to adjacent coastal waters; the megalopa returns later to the lagoon for settlement and metamorphosis (Anger et al., 1994). As a consequence of this ontogenetic migration pattern, the larvae of C. granulata are exposed to great variations in environmental conditions such as temperature and salinity, in particular at the beginning and the end of the pelagic phase.

As one of the abiotic key factors, temperature controls the rates of survival, development, and metabolism in crab larvae and other poikilothermic organisms (Kinne, 1970). In coastal lagoons, where the zoed larvae of C. granulatu hatch and the megalopa settles, it may vary by more than $10^{\circ} \mathrm{C}$ within a single tidal cycle (Anger et al., 1994). While metabolic adaptations to temperature changes in the intertidal habitat have been investigated in adult C. granulata (Santos et al., 1987), nothing was known about the ontogeny of respiratory and other bioenergetic traits in the species. Hence, the aim of this study has been to quantify effects of temperature on survival, development, and oxygen consumption in its larval stages. Developmental changes in their temperature response are compared with the expected patterns of environmental changes that should be encountered by the planktonic larvae during their ontogenetic migrations between warm coastal lagoons and cooler marine waters.

\section{MATERIAL AND METH IODS}

Ovigerous females were collected from the Mar Chiquita Lagoon (Mar del Plata, Argentina; for description of habitat conditions see Spivak et al., 1994), transported to the marine laboratory of the Biologische Anstalt Helgoland (Germany), and then kept in aquaria with brackish water (ca $20 \%$ ) at a constant temperature $\left(18^{\circ} \mathrm{C}\right)$. After hatching, actively swimming larvae from one hatch were transferred individually to vials with ca $30 \mathrm{ml}$ filtered seawater (ca $32 \%$ ). Fifty larvae were reared at five different constant temperature levels $\left(12,15,18,21,24^{\circ} \mathrm{C}\right)$ and under a $12: 12 \mathrm{~h}$ light:dark cycle. In daily intervals, water was changed, vials were checked for moults or mortality, and the larvae were fed with freshly hatched Artemia sp. nauplii. The larval stages were identified using the morphological description by Boschi et al. (1967).

In another experiment, larvae were mass-reared at constant $18^{\circ} \mathrm{C}$ in gently aerated beakers with $5 \mathrm{~L}$ seawater. When moults occurred, the developmental stages were separated in different bowls so that all larvae in the same bowl had the same age within a given instar. In each stage, respiration was measured during exposure to $12,15,18,21$. 
and $24{ }^{\circ} \mathrm{C}$, using the Winkler method (Grasshoff, 1976). These measurements were carried out exclusively in intermoult (stage $C$ of the moulting cycle; Anger, 1983), because there is little developmental variability in oxygen consumption during this phase (Anger, 1991). Each measurement comprised seven replicate experiments (with larvae) and four replicate blanks (without larvae). Depending on larval weight and temperature, 2 (megalopa) to 45 (zoea I) individuals were confined in each Winkler bottle with ca $60 \mathrm{ml}$ Millipore-filtered $(0.25 \mu \mathrm{m})$ seawater. The larvae were not fed for two hours before the beginning of the experiment in order to avoid defecation inside the bottle Oxygen consumption was measured after an incubation period of $c a 15 \mathrm{~h}$, using a semiautomatic Metrohm Dosimat 665 titration apparatus. Larval respiration was calculated from the difference in $\mathrm{O}_{2}$ concentration between experimental and blank bottles, the volume and number of individuals in each bottle, and the time of incubation (Anger \& Jacobi, 1985). The temperature coefficient $\left(Q_{10}\right)$ for both the instantaneous (daily) rates of development (i.e. the reciprocal values of development duration, $D^{-1}$ ) and for the rates of respiration was calculated according to Van't Hoff's equation (Precht et al., 1973).

In samples taken from the same material, five replicate measurements of dry weight ( $W$ ) were carried out, with 3 (megalopa) to 20 (zoed I) individuals each. The larvae were briefly rinsed in water trom an ion exchanger to remove adherent salts, pipetted to a filter paper and then transferred with tweezers to pre-weighed tin cartridges. They were freeze-dried over night in a GT2 (Leybold-Heraeus) apparatus, before $W$ was measured on a Mettler U.M3 microbalance to the nearest $0.1 \mu \mathrm{g}$. In the present paper, $W$ data are used only for the calculation of weight-specific respiration rates (QO.) and to show the relationships between $W$ and respiration. A complete account of larval growth and elemental composition (carbon, nitrogen) is given elsewhere (Anger \& Ismael, 1997).

Statistical analyses were made using a "Statistical Analysis System" software package (SAS, 1989). Survival rates were compared using a $\chi^{2}$ test, while multiple comparisons of mean weight-specific respiratory rates were carried out using a two-way A.NOVA followed by Tukey's tests (Sokal \& Rohlf, 1981). Relationships between development duration, respiration, dry weight, and temperature are described with non-linear regression equations (exponential and power function models). After linearization (logarithmic transformation), regression coefficients were compared for parallelity with a t-test (Brownlee, 1965).

\section{RESULTS}

Chasmagnathus granulata larvae were able to develop successfully to the first juvenile crab stage at temperatures ranging from $15^{\circ}$ to $24^{\circ} \mathrm{C}$ (Fig. 1a). At $12^{\circ} \mathrm{C}$, mortality was high in all stages, particularly in the first and the last zoeal stage (Fig. $1 \mathrm{~b}$ ). the last survivors dying in the Megalopa stage before reaching metamorphosis. Maximum survival was observed at $18{ }^{\circ} \mathrm{C}$, with $92 \%$ of all larvae passing successfully through all four zoeal stages and $60 \%$ reaching metamorphosis to the first juvenile stage (Fig. 1a). Survival in the first two zoeal stages was significantly higher at $18{ }^{\circ} \mathrm{C}$ than at all other temperature levels $(P<0.005$; Fig. 1 b). In the Megalopa, on the other hand, survival increased clearly with increasing temperature (Fig. 1b). 

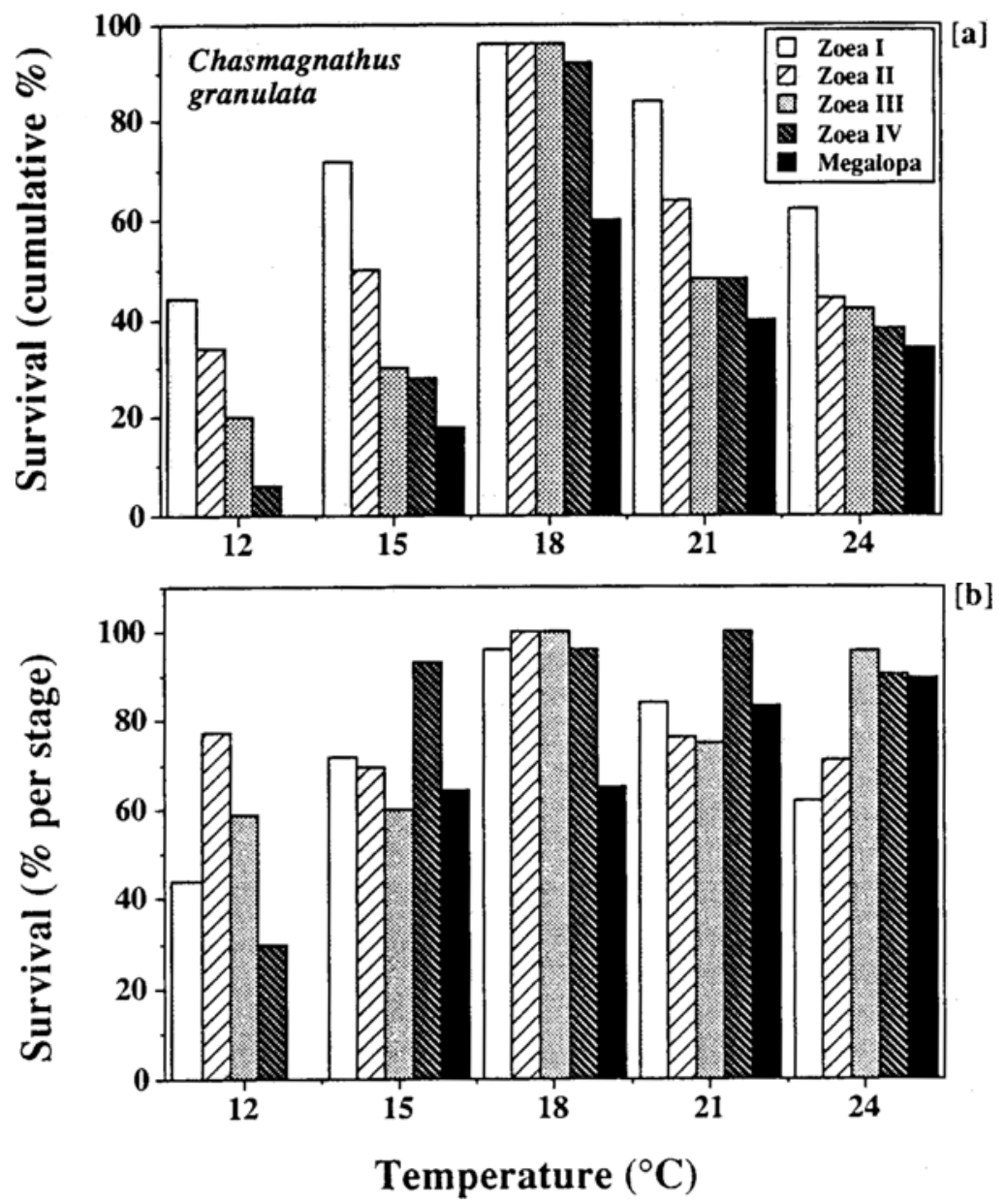

Fig. 1. Chasmagnathus granulata: (a) Cumulative. (b) stage-specilic rate of survival of larval stages reared at different temperatures ( $"(\cdots ;$ initial $n=50$ individuals per treatment)

The time of development ( $D$, in days) increased in successive larval stages, and it decreased in cach stage with increasing temperature (Table 1). The decrease in $D$ with increasing temperature $\left(T ;\right.$ in $\left.{ }^{\circ} \mathrm{C}\right)$ can be expressed with the following general regression model (power function), where $b$ is the intercept with the $Y$ axis and $m$ the slope (regression coefficient) in the linearized form (after log-transformation of both $D$ and $T$ ):

$$
D=b \cdot T^{m}
$$

The fitted regression curves and equations are shown in Figure 2a, along with the coefficients of determination, $r^{2}$ (all $\geq 0.97$; significantly different from zero; $P<0.01$ ). The slopes of these regressions were lower in the Zoea I, Zoea II and Megalopa than in 

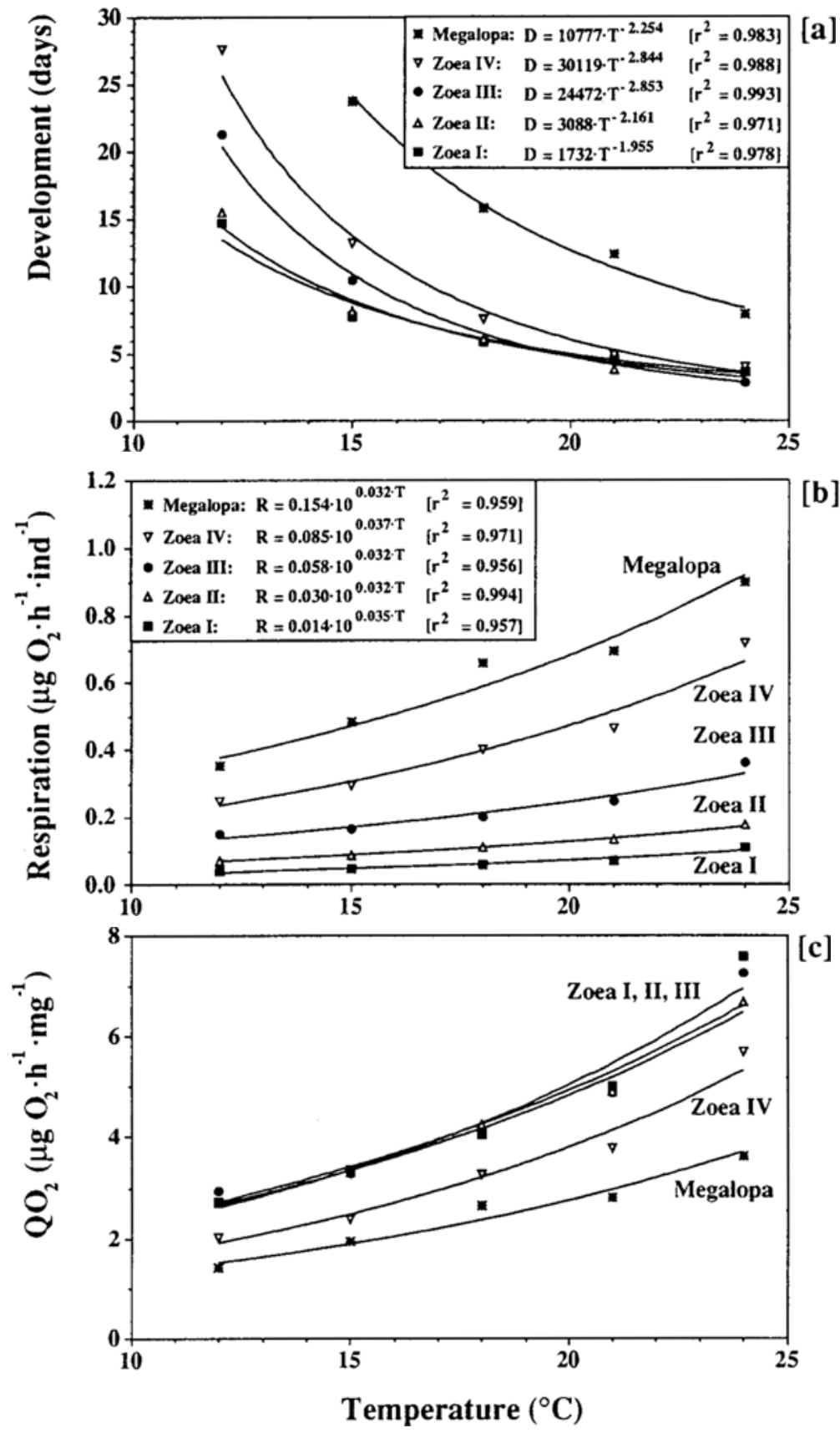

Fig. 2. Chasmagnathus granulata: Fiffect of temperature $\left(T,{ }^{\circ} \mathrm{C}\right)$ on (d) duration of development $(D$. days), (b) individual respiration $(R)$. (c) weight-specific rate of respiration $\left(Q O_{2}\right)$ in successive larval stages; for $\bar{x} \pm$ SD see Table 1 . Non-linear regression equations (Eqs. 1, 2; see text) given with fitted parameters and coefficients of determination, $\mathrm{r}^{2}$ 
the Zoea III and IV stages ( $m=-2.0$ to -2.2 vs. -2.8 ); however, these differences were not statistically significant $(P>0.05)$.

In mass-cultures kept at constant $18^{\circ} \mathrm{C}$, the larvae showed similar development duration and survival as in the individual cultures. Average larval dry weight $(W)$ during the intermoult (stage C) period of the moulting cycle was 14.5, 27.0, 50.4, 123.6, and $259.7 \mathrm{\mu g}$ per individual, respectively, in the successive developmental stages (Zoea I-IV, Megalopa). Simultaneously determined individual respiration rates $(R)$ increased significantly with both increasing temperature and developmental stage (Table 1). In all larval stages, $R$ can be described as an exponential function of temperature (Fig. 2b):

$$
R=b \cdot 10^{m \cdot r}
$$

[Eq. 2]

Table 1. Chasmagnathus granulata: Duration of development ( $D$; days), rates of individual respiration $\left(R_{i} \mu \mathrm{g} \mathrm{O}_{2} \cdot \mathrm{h}^{\prime} \cdot\right.$ ind $\left.{ }^{1}\right)$, and weight-specific metabolism $\left(\mathrm{QO}_{2 ;} \mu \mathrm{g} \mathrm{O} \mathrm{O}_{2} \cdot \mathrm{h}^{1} \cdot \mathrm{mg}^{-1}\right)$ of successive larval stages $(\bar{x} \pm S D)$ at different temperatures.

\begin{tabular}{|c|c|c|c|c|c|c|c|}
\hline \multirow{2}{*}{$\begin{array}{l}\text { Larval } \\
\text { Stage }\end{array}$} & & & \multicolumn{5}{|c|}{ Temperature $\left({ }^{\circ} \mathrm{C}\right)$} \\
\hline & & & 12 & 15 & 18 & 21 & 24 \\
\hline \multirow[t]{6}{*}{ Zoea I } & \multirow[t]{2}{*}{$D$} & $\bar{x}$ & 14.7 & 7.7 & 5.9 & 4.6 & 3.6 \\
\hline & & \pm & 1.3 & 0.4 & 0.6 & 0.3 & 0.2 \\
\hline & \multirow[t]{2}{*}{$R$} & $\bar{x}$ & 0.040 & 0.049 & 0.058 & 0.072 & 0.112 \\
\hline & & \pm & 0.002 & 0.006 & 0.004 & 0.009 & 0.008 \\
\hline & \multirow[t]{2}{*}{ QO: } & $x$ & 2.73 & 3.36 & 4.04 & 5.00 & 7.59 \\
\hline & & \pm & 0.17 & 0.43 & 0.35 & 0.68 & 0.59 \\
\hline \multirow[t]{6}{*}{ Zoea Il } & \multirow[t]{2}{*}{$D$} & $\dot{x}$ & 15.5 & 8.1 & 6.1 & 3.8 & 3.6 \\
\hline & & \pm & 2.1 & 0.8 & 1.2 & 0.7 & 0.7 \\
\hline & \multirow[t]{2}{*}{$R$} & $\dot{x}$ & 0.073 & 0.088 & 0.110 & 0.134 & 0.178 \\
\hline & & \pm & 0.00 .3 & 0.005 & 0.014 & 0.006 & 0.012 \\
\hline & \multirow[t]{2}{*}{$Q \mathrm{O}_{2}$} & $\dot{x}$ & 2.70 & 3.31 & 4.23 & 4.90 & 6.68 \\
\hline & & \pm & 0.14 & 0.19 & 0.38 & 0.16 & 0.48 \\
\hline \multirow[t]{6}{*}{ Zoed III } & \multirow[t]{2}{*}{$D$} & $\overline{\mathrm{x}}$ & 21.3 & 10.4 & 5.9 & 4.5 & 2.8 \\
\hline & & \pm & 3.9 & 1.5 & 0.7 & 0.7 & 0.4 \\
\hline & \multirow[t]{2}{*}{$R$} & $\bar{x}$ & 0.148 & 0.165 & 0.202 & 0.247 & 0.360 \\
\hline & & \pm & 0.008 & 0.006 & 0.020 & 0.014 & 0.038 \\
\hline & \multirow{2}{*}{$\mathrm{OO}_{2}$} & $\bar{x}$ & 2.93 & 3.27 & 4.08 & 4.86 & 7.24 \\
\hline & & \pm & 0.16 & 0.13 & 0.27 & 0.15 & 0.77 \\
\hline \multirow[t]{6}{*}{ Zoea IV } & \multirow[t]{2}{*}{$D$} & $\bar{x}$ & 27.6 & 13.1 & 7.5 & 4.9 & 4.0 \\
\hline & & \pm & 0.8 & 1.5 & 0.6 & 0.5 & 0.4 \\
\hline & \multirow[t]{2}{*}{$R$} & $\overline{\mathrm{x}}$ & 0.249 & 0.296 & 0.402 & 0.465 & 0.720 \\
\hline & & \pm & 0.009 & 0.019 & 0.032 & 0.013 & 0.080 \\
\hline & \multirow[t]{2}{*}{$\mathrm{QO}_{2}$} & $\bar{x}$ & 2.01 & 2.39 & 3.25 & 3.76 & 5.68 \\
\hline & & \pm & 0.07 & 0.15 & 0.26 & 0.11 & 0.56 \\
\hline \multirow[t]{6}{*}{ Megalopa } & \multirow[t]{2}{*}{$D$} & $\dot{x}$ & & 23.7 & 15.8 & 12.3 & 7.9 \\
\hline & & \pm & & 3.9 & 2.0 & 2.0 & 1.4 \\
\hline & \multirow[t]{2}{*}{$R$} & $\bar{x}$ & 0.353 & 0.484 & 0.658 & 0.695 & 0.899 \\
\hline & & \pm & 0.020 & 0.082 & 0.095 & 0.060 & 0.256 \\
\hline & \multirow[t]{2}{*}{$\mathrm{QO}_{2}$} & $\bar{x}$ & 1.42 & 1.95 & 2.65 & 2.80 & 3.62 \\
\hline & & \pm & 0.08 & 0.32 & 0.38 & 0.24 & 1.03 \\
\hline
\end{tabular}


The slopes (coefficient $m$ ) of these regression equations were, agairl, significantly different from zero $\left(\mathrm{r}^{2}=\geq 0.96 ; P<0.01\right)$, and no significant differences occurred between different larval stages ( $m$ ranging from 0.032 to 0.037 ; Fig. $2 b$ ).

Among the dry-weight $(\mathrm{W})$ specific metabolic rates $\left(Q \mathrm{O}_{2}\right)$ measured at equal temperatures, no significant differences were found between the Zoea I, II, and III stages (Tukey test: $P>0.05$; Table 1), in spite of a more than three-fold increase in body
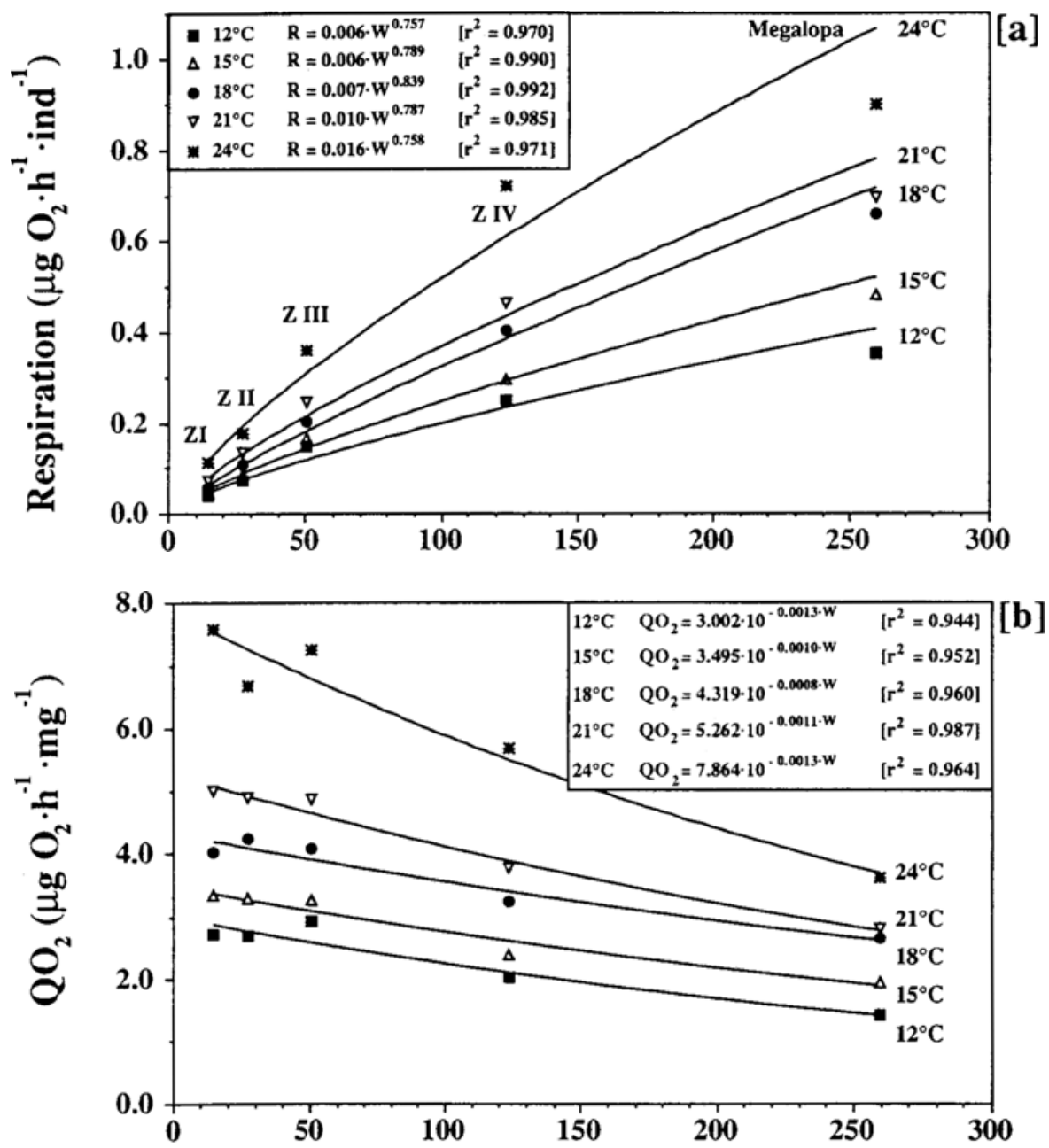

Dry weight $(\mu \mathrm{g} /$ ind $)$

Fig. 3. Chasmagnathus granulata: Effect of larval body weight ( $W, \mu g / i n d i v i d u a l)$ on rates of (a) individual respiration $(R)$, (b) weight-specific respiration $\left(Q O_{2}\right)$ in successive larval stages; for $\overline{\mathrm{x}} \pm \mathrm{SD}$ see Table 1 . Non-linear regression equations (Eqs 1, 2; see text) given with fitted parameters and coefficients of determination, $r^{2}$ 

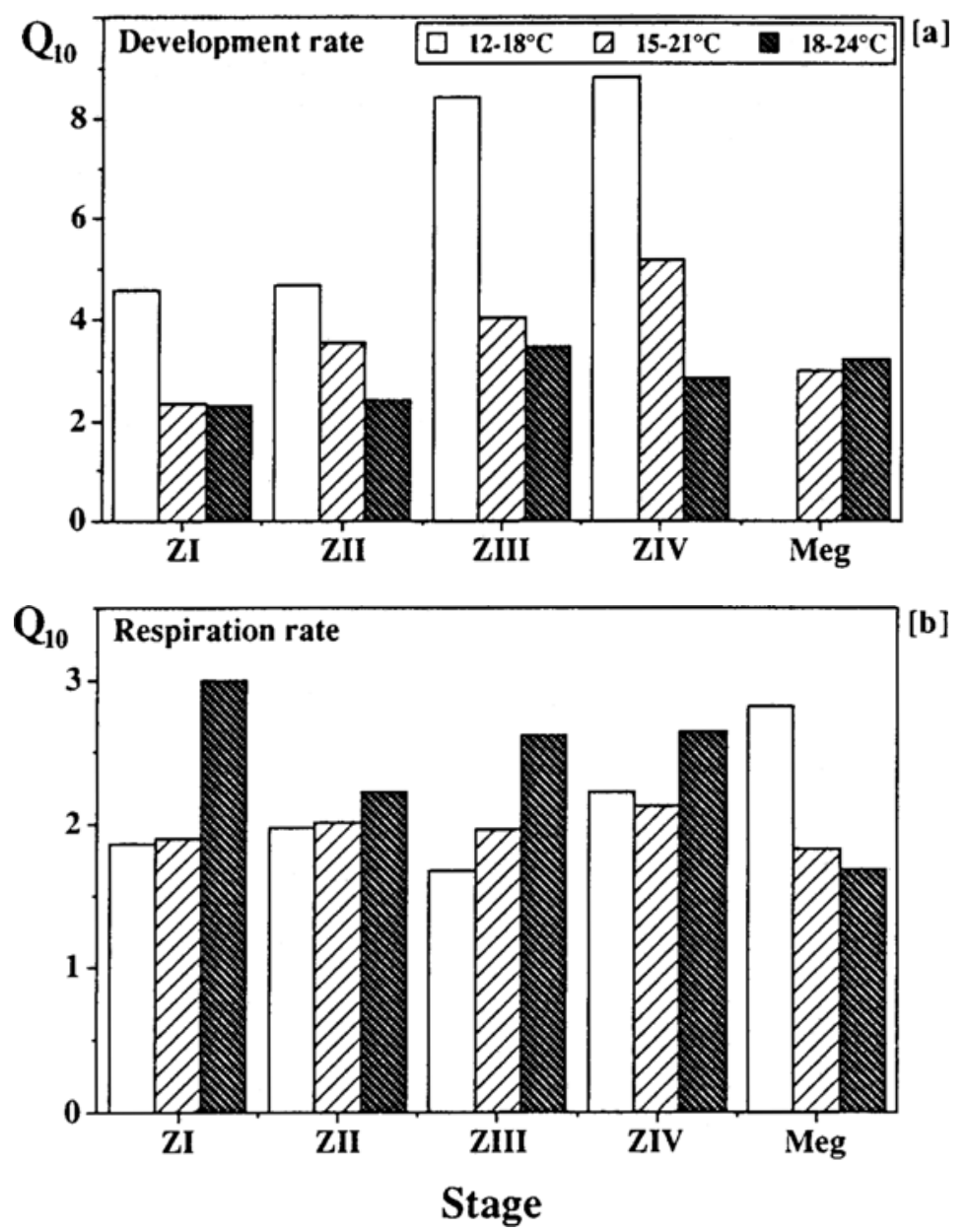

Fig. 4. Chasmagnathus granulata: Temperature coefficient $\left(Q_{11}\right)$ of $(d)$ instantaneous rate of development $(D),\left(\right.$ b) respiratory rate $\left(R, Q O_{2}\right)$ in successive larval stages

weight (see above). In the Zoea IV and Megalopa stages, however, the $\mathrm{QO}_{2}$ values decreased significantly with increasing $W$ (Tukey test, $P<0.05$ ). As in the individual respiration rates $(R)$, the $Q \mathrm{O}_{2}$ values increased in all larval stages significantly with increasing temperature (Fig. 2c). Since these two measurements of the metabolic rate are linked by a constant factor $\left(Q O_{2}=R / W\right)$, the temperature-dependence of both $R$ and $Q O_{2}$ can be described with the same regression model (Eq. 2), and identical $\mathrm{r}^{2}$ values are obtained (equations thus not shown in Fig. 2c).

The relationships between metabolic rate and individual dry weight are shown in Figure 3. Individual respiration, $R$, increased in a parabola-shaped manner with increasing $W$, which can be described with a power function (Eq. 1; Fig. 3a). The 
regression coefficients $(m)$ of these allometric equations varied only little among the larval stages, ranging from 0.76 to 0.84 . As in the temperature-dependence of $R$ described above, all slopes were significantly different from zero $\left(r^{2} \geq 0.97 ; P<0.01\right)$. When $\mathrm{QO}_{2}$ is plotted against dry weight, best fit of observed and predicted data is obtained with the exponential model (Eq. 2; Fig. 3b). Since $\mathrm{QO}_{2}$ did not change significantly with $W$ in the first three zoeal stages, the overall relationship was relatively weak, yet significant $\left(\mathrm{r}^{2} \geq 0.94 ; P<0.05\right)$. The slopes varied between values of -0.0008 and -0.013 , with a minimum at the optimum temperature, $18^{\circ} \mathrm{C}$. In contrast, the weight-dependence of $R$ was maximum at the same temperature (Fig. 3a).

In Figure 4, the temperature response (expressed as temperature coefficient, $Q_{10}$ ) in respiration rate is compared with that in development duration. There is a conspicuous difference in the overall response patterns, being partially opposite to each other. In the instantaneous (daily) development rate $\left(D^{-1}\right)$, the temperature coefficient was in all zoeal stages consistently maximum in the lower range $\left(12-18^{\circ} \mathrm{C}\right)$ and minimum at higher temperatures $\left(18-24^{\circ} \mathrm{C}\right)$. It showed consistently an increasing tendency during development through the successive instars (Fig. 4a). The Megalopa, in contrast, had lower developmental $Q_{10}$ values than the zoeal stages, and the coefficient did not change within the range from 15 to $24^{\circ} \mathrm{C}$ (no data for $12{ }^{\circ} \mathrm{C}$, due to mortality). The respiratory $Q_{11}$ values varied also with both the temperature range and the developmental stage, but with a different response pattern (Fig. 4 b). In general, no conspicuous developmental change in the overall level of the metabolic temperature-dependence can be recognized. However, while all zoeal stages had consistently a maximum $Q_{11}$, in the higher temperature range (18-24 $\left.{ }^{\circ} \mathrm{C}\right)$, the Megalopa showed the opposite trend (Fig. $4 \mathrm{~b}$ ).

\section{DISCUSSION}

The thermal tolerance patterns of Chasmagnathus granulata larvae observed in our study (Fig. 1) reflect the geographical distribution of this species in predominantly temperate and subtropical, and to a lesser extent, in tropical regions (Boschi, 1964). Complete larval development occurs in moderately warm water $\left(15\right.$ to $\left.24{ }^{\circ} \mathrm{C}\right)$, whereas a lower temperature $\left(12{ }^{\circ} \mathrm{C}\right)$ did not allow for successful metamorphosis. The optimum was found at $18^{\circ} \mathrm{C}$, with significantly higher survival than at all other temperature levels. This sensitivity of larval stages to low temperatures is in accordance with the observation that hatching in the coastal lagoon of Mar Chiquita (Argentina) occurs from spring to autumn, when the coastal water temperature is usually at $\geq 18{ }^{\circ} \mathrm{C}$, but not in winter, when the average water temperatures fall below $12^{\circ} \mathrm{C}$ (Boschi, 1964; Spivak et al., in press). In subtropical regions such as southern Brazil, in contrast, reproduction has been observed throughout the year (Ruffino et al., 1994). Decreasing larval tolerance of yet higher temperatures $\left(>21^{\circ} \mathrm{C}_{;}\right.$Fig. 1$)$ may be responsible for the northern distribution limit of this crab species, which has been found only little beyond the southern margin of the tropical belt, near Rio de Janeiro (Boschi et al., 1992).

Besides survival, the rate of larval development is controlled by temperature. Exponents of -2.0 to -2.8 in the power functions describing this relationship (Fig. 2a) indicate that development in C. granulata is highly influenced by temperature. Since the length of planktonic development has implications for the chance of survival, tempera- 
ture also determines the time of exposure to pelagic predation (Day \& McEdward, 1984; Morgan, 1995). The degree of temperature-dependence of the developmental rate (measured here as $Q_{1 \prime}$ coefficient) was higher in the planktonic zoeal stages than in the semibenthic Megalopa, and it was, in general, particularly high in the lower temperature range $\left(12-18^{\circ} \mathrm{C}\right.$; Fig. $\left.4 \mathrm{a}\right)$. Hence, during the zoeal phase, this abiotic factor may enhance the effects of a biotic factor, predation pressure, so that a combination of both the direct and indirect adverse effects of low temperatures may limit the southern range of $C$. granulata. This species does not occur in the cold waters of the southern Patagonian coasts or adjacent estuaries. However, as another limiting parameter in the distribution of this crab species, the presence or absence of its preferred habitat, i.e. brackish salt marshes, may be crucial in some regions (Boschi, 1964; Olivier et al., 1972; Spivak et al., 1994). In the Megalopa stage, temperature has less influence on the duration of development to settlement and metamorphosis. This final period is additionally controlled by another key factor, chemical cues from the adult habitat (Gebauer et al., 1997).

The overall patterns of respiration in relation to temperature and body weight (Figs 2, 3) are similar between C. granulata and most other larval decapods studied so far (e.g. Moreira et al., 1981; Vernberg et al., 1981; McNamara et al., 1985; Anger \& Jacobi, 1985; Kurmaly et al., 1989). While the commonly known increase of individual respiration $(R)$ with increasing temperature (Fig. 2 b) has been described in the literature with various non-linear models, its increase with increasing weight (Fig. 3a) generally follows an allometric function (Eq. 1), mostly with an exponent of ca 0.7 to 1.0 (for discussion of literature see Schatzlein \& Costlow, 1978). The general decrease in weight-specific metabolic rates $\left(Q O_{2}\right)$ during growth is considered to be a consequence of a disproportionate increase of metabolically inactive tissues (Prosser, 1986). For instance, the weight of the exoskeleton increases exponentially during the larval development of C. granulata and other decapod crustaceans (Anger, 1991; Anger \& Ismael, 1997). In the present study, however, the $Q O_{2}$ values did not vary significantly among the first three zoeal stages, while decreasing trends were found in the later stages.

In the brackish coastal lagoon of Mar Chiquita, Argentind, from where the present material originated, C. granulata larvae are released in shallow waters adjacent to the adult habitat, Spartina-covered salt marshes, preferably during outflowing nocturnal ebb tides (Anger et al., 1994). After complete zoeal development in coastal marine waters, the Megalopa returns from the ocean to the lagoon, settling preferably in habitats where adult populations live (Luppi, 1994; Gebauer et al., 1997). In the zoeal stages, we observed a particularly high metabolic sensitivity to small changes in the upper temperature range (above $18{ }^{\circ} \mathrm{C}$; Fig. $4 \mathrm{~b}$ ), which may reflect their exclusive occurrence in cool and thermally stable marine waters. The Megalopa, in contrast, which spends a major part of its development in warm and thermally variable estuarine environments, showed little sensitivity at high, but a pronounced response at low temperatures. This corresponds, in this stage, with a clearly decreasing mortality at higher temperatures (Fig. 1b). A similar pattern, with consistently highest $Q_{10}$ values in the lower temperature range, was found also in the zoeal stages of another intertidal warm-water decapod, the South American hermit crab Pagurus criniticornis (Vernberg et al., 1981). As in C. granulata, conspicuously lower $Q_{10}$ values were observed in the Megalopa, which should also return from cooler offshore waters to the warm shallow coastal zone. 
These striking ontogenetic patterns in the metabolic temperature response suggest that the larval stages of $C$. granulata (and possibly those of other intertidal and estuarine species) are adaptated to a sequence of thermal changes that should typically occur during their ontogenetic migrations. In conclusion, we speculate that a high sensitivity to small temperature changes might serve as a signal that stimulates a specific migratory behaviour (for migration patterns and transport mechanisms see e.g. Cronin \& Forward, 1986; Sulkin, 1990; McConaugha, 1992; Zeng \& Naylor, 1996a, b). In the zoeal stages, warm water would indicate that larvae have been retained in an estuary and should thus be carried in the outflowing surface currents, while cooler water could be an indicator of favourable marine conditions. However, an avoidance behavior (passive sinking) must be expected at unsuitably high temperatures (McConnaughey \& Sulkin, 1984; Forward, 1990). The Megalopa, in contrast, might be stimulated by cooler temperatures to initiate a landward directed migration (for behavioural and transport patterns of megalopae see e.g. Little \& Epifanio, 1991; Olmi, 1994). This thermally controlled behavioural mechanism, probably in combination with a response to salinity changes, would assure an efficient transport towards the sea in the zoeal stages, and towards shallow coastal lagoons and estuaries in the Megalopa, respectively. Ontogenetic migrations have been extensively studied in the larvae of several other estuarine decapod species, and a number of physical and chemical control factors have been identified (e.g. De Vries et al., 1994; Olmi, 1994; Forward et al., 1996; and earlier papers cited therein). Our results suggested that the metabolic response to differential temperature regimes prevailing in estuarine and offshore waters, respectively, may represent another stimulus aiding in the orientation of migrating decapod larvae.

Acknowledgments. We thank U. Süsens, K. Riesebeck, C. Püschel for technical help. The first author would like to thank Dr. Luiz Carlos Baida (CNESP, S. J. Rio Preto, SP, Brazil) for helping with the statistical procedures. This research was supported by the Deutscher Akademischer Aus:aischierst 'Born, Gor:any Grant 32250328:2) and the "Corselno Nacional cie Desenvolvimento Cientifico e Tecnológico" (Brasilia. Brazil, Grants 840064/90-0 and 840167/94-6).

\section{LITERATURE CITED}

Anger, K., 1983. Moult cycle and morphogenesis in Hyas araneus larvae (Decapoda, Majidae). reared in the laboratory. - Helgoländer Meeresunters. 36, 285-302.

Anger, K., 1991. Developmental changes in the bioenergetics of decapod larvae. - Mem. Qd Mus 31. 289-308.

Anger, K., 1995. The conquest of freshwater and land by marine crabs: adaptations in life-history patterns and larval bioenergetics. - J. exp. mar. Biol. Ecol. 193, 119-145.

Anger, K. \& Ismael, D., 1997. Growth and elemental composition (C, N, H) in larvae and early juveniles of a South American salt marsh crab, Chasmagnathus granulata (Decapodd: Grapsidae). - Mangroves and salt marshes 1, 219-227.

Anger, K. \& Jacobi, C. C., 1985. Respiration and growth of Hyas araneus L. larvae (Decapodd. Majidae) from hatching to metamorphosis. - J. Exp. Mar. Biol. Ecol. 88, 257-270.

Anger, K., Spivak, E., Bas: C., Ismael, D. \& Luppi, T., 1994. Hatching rhythms and dispersion of decapod crustacean larvae in a brackish coastal lagoon in Argentina. - Helgoländer Meeresunters. 48, 445-466.

Boschi, E. E., 1964. Los Crustáceos Decápodos Brachyura del Litoral Bonaerense. - Boln Inst. Biol. mar., Mar del Plata $6,1-74$ 
Boschi, E. E., Scelzo, M. A. \& Goldstein, B., 1967. Desarrollo larval de dos especies de Crustáceos Decápodos en el laboratorio. Pachycheles haigae Rodrigues Da Costa (Porcellanidae) y Chasmagnathus granulata Dana (Grapsidae). - Boln Inst. Biol. mar. Mar del Plata 12, 1-46.

Boschi, E. E., Fischbach, C. E. \& lorio, M. I., 1992. Catálago ilustrado de los crustáceos estomatópodos y decápodos marinos de Argentina. - Frente marit., Uruguay: 10, 7-94.

Brownlee, K. A., 1965. Statistical theory and methodology in science and engineering. Wiley, New York, $590 \mathrm{pp}$.

Cronin, T. W. \& Forward, R. B., 1986. Vertical migration cycles of crab larvae and their role in larval dispersal. - Bull. mar. Sci. 39, 192-201.

Day, R. \& McEdward, L., 1984. Aspects of the physiology and ecology of pelagic larvae of marine benthic invertebrates. In: Marine plankton life cycle strategies. Ed. by K. A. Steidinger \& L. M. Walker. CRC Press, Boca Raton, 94-120.

DeVries, M. C., Tankersley, R. A., Forward, R. B., Kirby-Smith. W. W. \& Luettich, R. A., 1994. Abundance of estuarine crab larvae is associated with tidal hydrologic variables. - Mar. Biol. $118,403-413$.

Forward, R. B., 1990. Behavioral responses of crustacean larvae to rates of temperature change. Biol. Bull. mar. biol. Lab., Woods Hole 178, 195-204.

Forward, R. B., De Vries, M. C., Rittschof, D., Frankel, D. A. Z., Bischoff, J. P., Fisher, C. M. \& Welch. J. M., 1996. Effects of environmental rues on metamorphosis of the blue crab Callinectes sapidus. - Mar. Ecol. Prog. Ser. 131, 165-177.

Gebauer, P., Walter, 1. \& Anger, K., 1997. Effects of substratum and conspecific actults on the metamorphosis of Chasmagnathus granulata (Dana) (Decapoda: Grapsidae) megalopae. - J. exp. Inar. Biol. Ecol. (in press).

Grasshoff, K., 1976. Methods of sea water andlysis. Verl. Chemie. Weinheim, 317 pp.

Hartnoll, R. R. 1988. Evolution, systematics and geographical distribution. In: Biology of the land crabs. Ed. by W. W. Burggren \& B. R. McMahon. Cambridge University Press, Cambridge, 6-54.

Kinne, O., 1970. Temperature. Invertebrates. In: Marine ecology. Ed by O. Kinne. Wiley. Chichester, 407-415.

Kurmaly, K., Yule, A. B. \& Jones, D. A., 1989. Effects of body size and temperature on the metabolic rate of Penceus monodon. - Mar. Biol. 103, 25-30.

Little, K. T. \& Epifanio, C. E., 1931. Mechanism for the re-invasion of an estuary by two species of brachyuran megalopae. - Mar. Ecol. Prog. Ser. 68, 235-242.

Luppi, T. A., 1994. La coexistencia de dos especies de cangrejos en el ecosistema del "Cangrejal". Estudio comparativo de los ciclos de vida. Thesis, Univ. Nacional de Mar del Plata, 54 pp.

McConaugha, J. R., 1992. Decapod larvae: dispersal, mortality, and ecology. A working hypothesis. - Am. Zool. 32, 512-523.

McConnaughey, R. A. \& Sulkin, S. D., 1984. Measuring the ettect of thermoclines on the vertical migration of larvae of Callinectes sapidus (Brachyurd: Portunidae) in the laboratory. - Mar. Biol. $81,139-145$

McNamara, J., Moreira, G. S. \& Moreira, P. S., 1985. Thermal effects on metabolism in selected ontogenetic stages of the freshwater shrimps Macrobrachium oliersii and Macrobrachium heterochirus (Decapoda, Palaemonidae). - Comp. Biochem. Physiol. 80A, 187-190.

Moreira, G. S., McNamara, F. C., Hiroki, K. \& Moreira, P. S., 1981. The effect of temperature on the respiratory metabolism of selected developmental stages of Emerita brasiliensis Schmitt (Anomuri, Hippidae). - Comp. Biochem. Physiol. 70A. 627-629.

Morgan, S. (j., 1995. Life and death in the plankton: larval mortality and adaptation. In: Ecology of marine invertebrate larvae. Ed. by L. R. McEdward. CRC Press, Boca Raton, 279-321.

Olivier, S., Fiscofet, A., Penchaszadeh, P. \& Orensanz, J., 1972. Estudios ecológicos de la región estuarial de Mar Chiquita (Bs. As. Argentina). I. Las comunidades bentónicas. - An. Soc. cient. Arg. 193, 237-262.

Olmi, E. J., 1994. Vertical migration of blue crab Callinectes sapidus megalopae: implications for transport in estuaries. - Mar. Ecol. Prog. Ser. 113, 39-54.

Precht, Fi. Christopherson, J., Hensel, H. \& Larcher, W., 1973. Temperature and life. Springer, Berlin. 501 pp.

Prosser, C. I.., 1986. Temperature. In: Adaptational biology. Ed. by C. L. Prosser. Wiley, New York, 260-322. 
Ruffino, M. L. Telles, M. D. \& J'Incao, F. 1994. Reproductive asperts of Chasmagnathus granuluta Dana, 1851 (Decapoda. Grapsidae) in the Patos Lagoon Estuary, Brazil. - Nauplius 2, 43-52.

Santos, E. A., Baldisseroto, B., Bianchinı, A., Colares, E. P., Nery, L. E. M. \& Manzoni, G. C., 1987. Respiratory mechanisms and metabolic adaptations of an intertidal crab, Chasmagnalhus granulata (Dand, 1851).-Comp. Biochem. Physiol. 88A, $21-25$.

S.AS (Statistical Analysis System). 1989. Institute Inc., version 6. 1st Edition. Cary. NC., USA.

Schatzlein, F. C.\& Costlow, J. D., 1978. Oxygen consumption of the larvae of the decapod crustaceans, Emerita talpoida (Say) and Libinia emarginata Leach. - Comp. Biochem. Physiol. 61A. 441-450

Sokal, R. R. \& Rohlf, F. J.. 1981. Biometry. Freeman, Sin Francisco, 8.59 pp.

Spıvak. E. Anger, K., Luppi, T. Bas, C. \& Ismael, D.. 1994. Distribution and habitat preferences of two grapsid crab species in Mar (Chiquita Lagoon (Province of Buenos Aires, Argentina). - Helgolander Meeresunters. 48, 59-78.

Spivak, E. D. Anger, K. Bas, C. C., Luppi, T. A. \& Ismael. D., 1998. Size structure, sex ratio, and breeding season in two intertidal grapsid crab species from Mar Chiquita Lagoon, Argentina. Neritica 10 (in press)

Sulkin, S. D., 1990, Larval orientation mechanisms: the power of controlled experiments. -- Ophelia $32,49-62$.

Vernberg, W. B. Moreira, G. S. \& McNamara, J. C.., 1981. The effect of temperature on the respiratory metabolism of the developmental stages of Pagurus criniticornis (Dana) (Anomura: Pagurldise) - Mar. Biol. 2. 1-9

Zeng, C. \& Naylor, E., 1996d. Endogenous tidal rhythms of vertical migration in field collected zoea-1 larvae of the shore crab Curcinus maenas: implications for ebb tide of fshore dispersal. Mar. Ecol. Prog Ser. 132, 71-82

Zenc, $\therefore$ \& Naylor. E. 1996h. Occurrence in codslal waters and endogenous tidal swimming rhythus of iate megalopae of the snore crob Carcinus maenas: implications ar onshore recribiment. - Mar Ecol. Prog Ser. 136, 139-79. 